\title{
Tunceli ili Çemişgezek ilçesinin kent merkezindeki tarihi yapılarındaki bozunma analizi
}

\author{
Murat DAL ${ }^{1, *}$, Ali Duran ÖCAL ${ }^{2}$ \\ ${ }^{1}$ Munzur Üniversitesi Mühendislik Fakültesi, Inşaat Mühendisliği Bölümü, Aktuluk kampüsü, Tunceli, \\ Türkiye. \\ ${ }^{2}$ Universidad Nacional de Colombia, Fakultad de Ciencias Humanas, Departamento de Antropologia, \\ Bogota, Kolombiya.
}

Geliş Tarihi (Recived Date): 13.01.2017

Kabul Tarihi (Accepted Date): 28.04.2017

\section{Özet}

Tunceli ili Çemişgezek ilçesindeki tarihi yapılarda yaygın olarak kullanılagelmiş doğal taş malzemeler, hava koşullarına bağll olarak çeşitli derecelerdeki bozunmalar görülmektedir. Doğal ortam koşulları ile insan kaynakl bozunma öğeleri arasındaki işbirliği taştaki bozunmanın türünü ve gücünü kontrol eder. Doğru bir ayrışma ve hasar bilgisi, ayrışma sürecini anlamaktaki gerekliliğin yanında, etkili koruma ölçülerinin belirlenmesinde de yardımc olabilir. Ayrışma özelliklerinin ve ayrışma formlarının, anıtın dış klsmının görsel analizi üzerine kurulan fenomenolojik prosedürlere göre incelenmesi olasıdır. Bu çalışmada, Çemişgezek ilçesindeki seçilmişs yapıların durumları incelenerek, ayrışma modelleri ele alınmıştır.

Anahtar kelimeler: Çemişgezek, doğal yapı taşı, tarihsel yapı, bozunma, tahribat.

\section{Analysis of deterioration of historical buildings in urban environments of Cemisgezek district of Tunceli province}

\begin{abstract}
The natural stones widely used at the historical buildings at Cemisgezek area in Tunceli Province are changed in several behaviors and to various degrees due to weathering. The collaboration between natural and anthropogenic weathering elements controls kind and strength of the alteration of stone material. Correct information on the weathering and damage is requisite to comprehend the weathering process that can help to determine effective preservation measurements. The weathering features are
\end{abstract}

\footnotetext{
*Murat DAL, teknikmurathoca@gmail.com, http://orcid.org/0000-0001-5330-1868

Ali Duran ÖCAL, adocal@unal.edu.co, http://orcid.org/0000-0003-2283-640X
} 
probable by phenomenological procedure that is established on visual analysis of the external part of monument and include the registering and mapping of the weathering forms. In this work, the evaluations of a state of selected building of Cemisgezek are presented, and a weathering model is discussed.

Keywords: Cemisgezek, natural building stone, historic building, weathering, destruction.

\section{Giriş}

Çemişgezek'te tarihi ve kültürel değeri yüksek olan yapılar, geçmişi günümüze bağlayan öğeler olarak farklı kültürlerin deneyimlerini yansıtmaları açısından büyük önem taşımaktadır. Yöreye özgü olan taşların kolay erişilebilirliğinden, yapı malzemesi olarak çok yaygın kullanıldığı görülmektedir. Doğal etkenlerin yanında olumsuz atmosferik koşullarının da etkilemesi nedeni ile yapıların fiziksel, kimyasal ve biyolojik bozunmaya neden oldukları burada da gözlenmektedir ve zaman içinde bu yapılar hızla tahrip olmaktadır.

Yerinde yapılan gözlem çalışmaları sonucunda, Çemişgezek bölgesinde yer alan tarihi yapılarda oluşan bozunmalar, atmosferik bileşiklerin etkileri $\left(\mathrm{SO}_{2}, \mathrm{NO}_{\mathrm{X}}, \mathrm{CO}_{2}\right.$, asit yağmurları) fiziksel etkiler (1s1, don, kapilarite, tuzlar), metal korozyonunun etkisi, canlılar, bitkiler ve mikroorganizma etkileri fiziksel çevre koşullarına bağlı olarak irdelenmiştir. Tarihi yapıların ve anıt eserlerin bozunmasına neden olan etkenlerin doğru ve erken saptanması, eserlerin ömrünü uzatmak için gerekli koruma yöntemlerini belirlemede ilk ve en önemli adımdır [1-3]. Bundan dolayı taş yapıların koruma çalışmalarının planlanmasında en önemli adımı bozunma nedenlerinin anlaşılması ve aşınma türlerinin belirlenmesidir. $\mathrm{Bu}$ bağlamda, Çemişgezek ilçesindeki tarihsel yapıların bozunma durumunun belgelenmesi, hem yöre insanlarına tarih bilincinin hatırlatılması, hem de yetkili mercilerin durumun farkına vararak vakit geçirmeden koruma işlemlerine başlanması açısından önem arz etmektedir.

\section{1. Çemişgezek ilçesinin tarihsel dokusu}

Çemişgezek tarihinin M.Ö. 4000 yıllarına dayandığı, Keban Barajı'nın inşası sırasında yapılan bilimsel araştırmalarda elde edilen bulgulardan anlaşılmaktadır. Çemişgezek ve çevresine İlkçağ' da Huriler, Hititler, Urartular, Medler, Persler, Roma İmparatorluğu; Ortaçağ'da Bizans İmparatorluğu, Büyük Selçuklu İmparatorluğu, Saltuklular, Artukoğulları, Anadolu Selçukluları, Karakoyunlular, Akkoyunlular; Yeniçağ'da ise Osmanlı İmparatorluğu egemen olmuştur. Anadolu Selçuklu Devleti, Çemişgezek'i 1200'lü yılların başında beylik merkezi haline getirmiştir. Çemişgezek Beyliği, Kanuni Sultan Süleyman zamanına kadar mevcudiyetini sürdürmüştür.

Tarihte ilk olarak Çemişgezek'ten, XVI. yüzyılda Şeref Han tarafından yazılmış Şerefname'de sözü geçer ve o dönemde yaşayan ailelerden ve soylarından bahsedilmektedir.

Bir yanda yörenin büyük ölçüde dağlık oluşu (Şekil 1), öte yanda ise önemli bir yerleşim birimine malik olmayışı (Tunceli ve çevresi) gezginlerin araştırmacıların, bilim adamlarının, hükümdarların uğrağı olmaktan uzak bırakmıştır [4]. 
Tahar vadisinin çöküntülerle genișleyen bir yerinde ve kayalık arazide kurulan kasaba, bugün iyi bir yerde olmamakla beraber sularının bolluğu ve yakın çevresi ile göz önünde bulundurulduğunda sahip olduğu verimli toprakları ve bilhassa savunmaya elverişli durumu ile eski insanlar için en uygun yerleşme yerlerinden biri olarak göze çarpmaktadır [4].

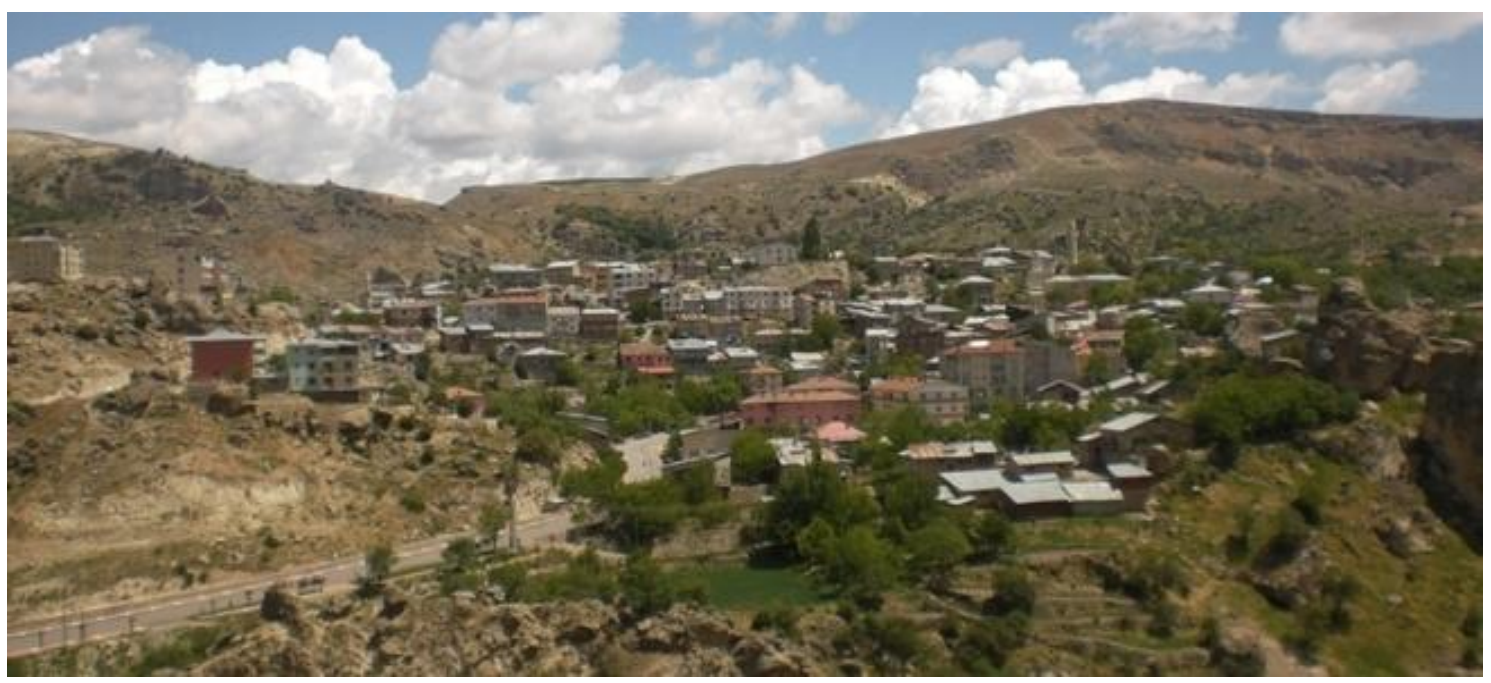

Şekil 1. Çemişgezek ilçesinin genel görünümü

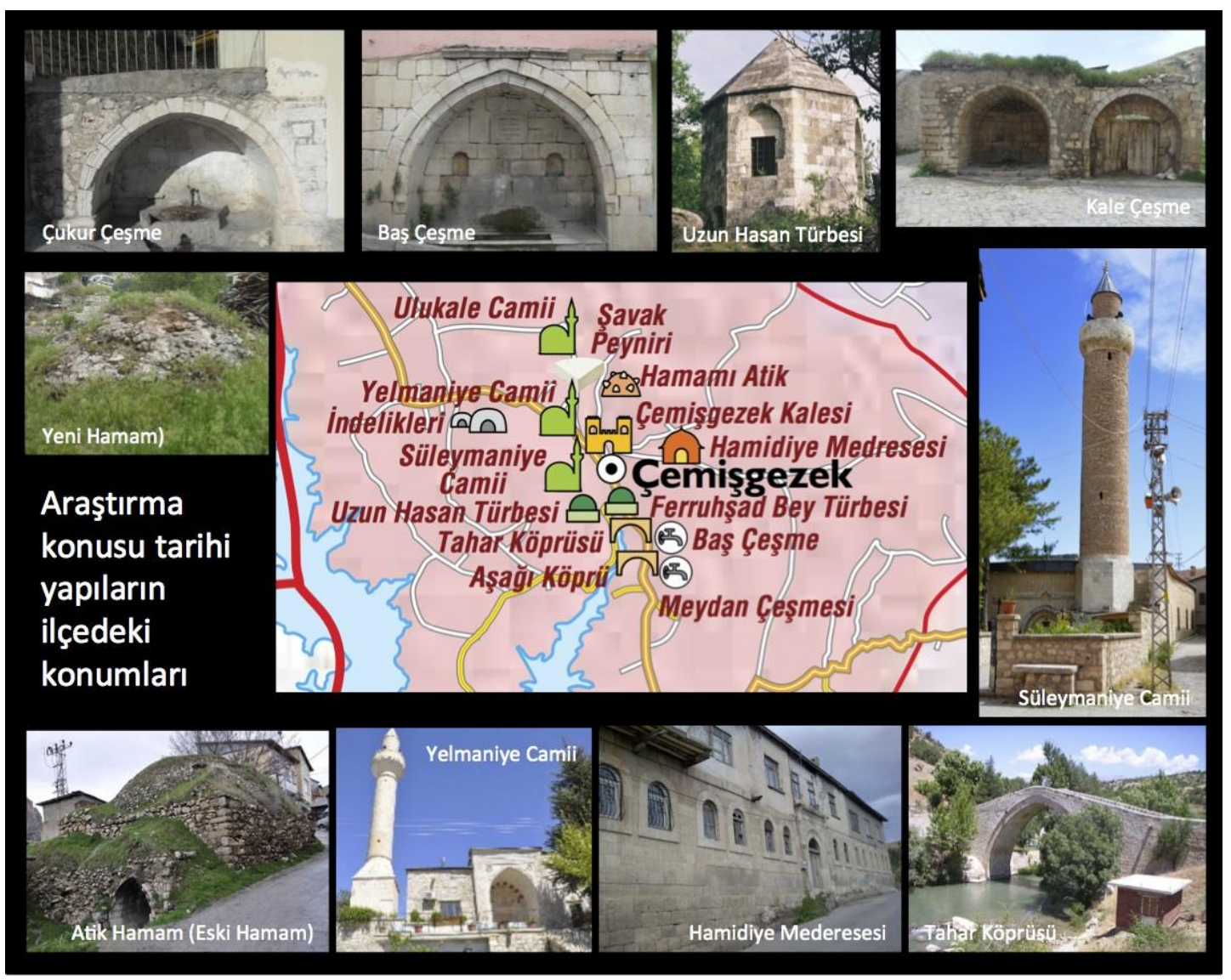

Şekil 2. Çemişgezek ilçesindeki araştırma konusu tarihi yapıların konumu (Harita Kaynak: Tunceli İl Kültür ve Turizm Müdürlüğü, 2015. Dağların ve Irmakların Şehri Tunceli Rehberi, Tunceli İli Valiliği, Tunceli) 
Selçuklular döneminde kırların yanı sıra, kentlere de aynı ölçüde önem verilmiştir. Hemen belirtelim ki, Selçuklular döneminde Türkiye'de yeni kentlerin temeli atılmamış olmakla beraber, varlığını yitirmiş veya sönükleşmiş kentler ve kasabalar taştan yapılmış medreseler, dini ve idari binalar yer almaya başladı [4].

Bölgemizdeki iskan yerlerinden bir çoğu daha evvel Osmanlılar veya Selçuklular zamanında Türkler tarafından kurulmuş veya geliştirilmiştir. O zamandan kalma kültür eserlerinden cami, hamam, han, köprü, su yoları, çeşme veya bunların örnekleri her tarafta mevcut olup halen Harput, Çemişgezek, Palu, Pertek, bu gibi eserlerce zengin yerlerdir [4].

Çemişgezek ilçesinde bulunan arkeolojik yerler arasında Pulur Höyüğü ile Yeniköy Höyüğü, tarihi yerler arasında da Uzun Hasan Türbesi, Hamami Atik (Eski Hamam), Çemişgezek Köprüsü, Ulukale Camisi ile Meydan Çeşmesinden sözedilebilir (Şekil 2).

\section{Materyal ve metot}

\subsection{Materyal}

\subsection{1. Çemişgezek ilçesinin tarihsel yapıları}

$\mathrm{Bu}$ çalışmanın ana amacı olan tahribat durumunun incelenerek görselleştirilmesi için Çemişgezek'teki 10 adet değişik türdeki tarihi yapı ele alınmıştır. Timur döneminde 14. yüzyıl başında yaptırıldığı sanılan Yelmaniye Camii ile mimari özellikleri Selçuklu tarzını yansıtan Süleymaniye Camisi; Akkoyunlular döneminden kalan Atik Hamam (Eski Hamam) ile bir Osmanlı yapısı olan Yeni Hamam; yine erken Osmanlı dönemine ait olan Baş Çeşme, Kale Çeşme ile Çukur Çeşme; Osmanlı döneminde inşa edilmiş olan Tahar (Yusuf Ziya Pasa) Köprüsü ve yine Osmanlı döneminden kalan Uzun Hasan Türbesi ile Osmanlıların son dönemlerinde yapılmış olan Hamidiye Medresesi, araştırma konusu olarak seçilmiştir.

Çemişgezek'teki inceleme konusu yapıların ve eski eserlerin ayrışma biçimlerinin sınıflandırılması çalışmaları kapsamında, değişik türdeki eserlerde gözlenen bozunma durumu anıt haritalaması metodu ile ayrıntılı olarak gösterilebilir. Bu konudaki çalışmaların temelini, Geologischen Institut der RWTH Aachen'daki "Natursteine und Verwitterung" Araştırma Grubu'nun geliştirdiği, fenomonolojik ayrışma kriterlerinin, eserler üzerindeki ayrıntılı analizleri ve belgelenmesi yoluyla oluşturmaktadır $[1,2,6-8$, 10]. Bu yolla yapının ve eserin ayrıntılı bir inceleme sonucunda bozunma sonuçlarının çizimler ve grafikler yardımıyla gösterilmesi esasına dayanmaktadır. Yapılara zarar vermeden gerçekleştirilen bu yöntem, kayaç eserin tüm yüzeyinin ayrıntılı bir bilgisini sunarak bozunmanın görsel bir değerlendirmesini sunmaktadır. Bu araştırma sürecinde daha önceden yayınlanmış çok sayıda kaynakçalardan yararlanılarak metodolojiye ve terminolojiye bağlı kalınarak çalışma tamamlanmıştır.

Gerçekleştirilen araştırma sürecinde üç aşamalı bir metodoloji kullanılmıştır. Çalışmanın ilk safhasını yapılarla ilgili ön hazırlıklar oluşturmuştur. İkinci aşamada, yapıların bulunduğu yerlere gidilerek gözlemler gerçekleştirilip geçici ayrışma durum haritası oluşturulmuştur. Çalışmanın son aşamasında ise oluşturulan geçici ayrışma durum haritasının değerlendirilerek yapıların ayrışma haritasıyla ilgili çalışmalar tamamlanmıştır. 


\section{Bulgular ve tartışma}

\section{1. Çemişgezek ilçesindeki tarihi yapıların incelenmesi}

Çemişgezek ilçesinde de, tüm ülke genelinde yaygın olarak gözlemlenebildiği gibi, taştan yapılmış tarihsel yapı ve eski eserlerin tahrip olmasında doğal iklim koşullarının en önemli faktör olarak gözükmesinin yanında özellikle artan nüfustan dolayı trafik yoğunluğu ve hava kirliliği ile bilinçsiz "onarım” çalışmaları, taş eserleri tehdit eden unsurları oluşturmaktadır. Çevresel faktörlerin yanında, yapıda kullanılan taşın mineralojik özelliklerinden kaynaklanan sorunlar da taşın bozunmasını hizlandirmaktadır.

\subsubsection{Yelmaniye camii}

Çemişgezek ilçe merkezi Tepebaşı (Medrese) Mahallesinde, ilçeye hakim bir tepede bulunan caminin, Timur zamanında Emir Taceddin Yelman Bin Keykubat Bin Halit elKürdi tarafından Hicri 800-809 tarihleri arasında medrese olarak yaptırıldığ 1 sanılmaktadır. Yelmaniye Camii'sinde gözlenen bozunma türlerini tuzlanma, form kaybı, çatlaklar, parça kaybı, lekelenme ile camii inşaasında kullanılan hatalı malzemeler olarak nitelendirilebilir.

\subsubsection{Süleymaniye camii}

Camii'nin yapım tarihini veren herhangi bir kitabe olmadığı gibi tarihi kaynaklarda da yap1 hakkında bilgi bulunmamaktadır. Yap1 plan, malzeme ve teknik özellikleri itibariyle değerlendirildiği takdirde Büyük Selçuklular ile başlayan ve Artuklular ile devam eden bölgesel mimari tarzını yansıtmaktadır. Süleymaniye Camii' sinde gözlenen bozunma türlerini yosun kolonizasyonu, yüzeyde biriken kirlenme, renk değişimi, bitki kolonizasyonu, oyuklanma, pürüzleşme ile restorasyon amaçlı kullanılan çimentodan kaynaklanan tahribatlar olarak sinıflandırılabilir.

\subsubsection{Atik hamam (Eski Hamam)}

İlçe merkezinde çarşı içinde yer alan yapının girişindeki Türkçe ve Arapça iki yazıttan hamamın, 15. Yüzyılda yapıldığı ve 18. yüzyılda da onarım gördüğ̈̈ anlaşılmaktadır. Yapıda meydana gelen bozunmaları kavlanma, boşluk-delik, kabuklanma ile insanların neden oldukları bozunmalar olarak nitelendirilebilir.

\subsubsection{Yeni hamam}

Yapı; Çemişgezek'in Çukur Mahallesi'nde Miladi 1701-1702 yılları arasında Hacı Bayram oğlu Hüseyin adında bir kişi tarafından inşa ettirildiği belirtilmektedir. Yapıda meydana gelen bozunmalara nemden dolayı oluşan mekanik ve kimyasal ayrışmanın yanında yapının artık kullanılmamasından kaynaklanan yoğun bitki örtüsü neden olmuştur.

\subsubsection{Baş çeşme}

Yap1; Çemişgezek ilçe merkezinde çarşı içinde bulunmaktadır. Çeşmenin alınlıkta bulunan kitabesinden Hicri 1287 tarihinde Rüştü Efendi tarafından tamir edildiği anlaşılmaktadır. Çeşmede gözlenen bozunmalar, parça kopması, yosun oluşumu ve derz boşalması olarak gözlenmektedir.

\subsubsection{Kale çeşmesi}

Yap1 hakkında herhangi bir bilgi bilinmemektedir. Sadece Çemişgezek Kale Mahallesinde bulunduğu bilinmektedir. Çeşmede gözlenen bozunmaları, kabuk 
oluşumu, rutubet-yosunlaşma, derz malzemesinin ayrışması, çatlaklar, 1sı genleşmeleri ve don ile çatıda görülen yüksek bitki tahribatı olarak sınıflandırılabilir.

\subsection{7. Çukur çeşme}

Çemişgezek ilçe merkezindeki, Çukur Mahallesinde bulunmaktadır. Daha önce Çukur Camii duvarları altında yer alan ve çeşme Çukur Camii'nin yıkılmış olması sebebiyle yalnız başına ayakta kalmıştır. Halen çeşme suyundan mahalle insanı faydalanmaktadır. Çesme'de gözlenen bozunmalar; bitkisel oluşumu ve isı etkisidir.

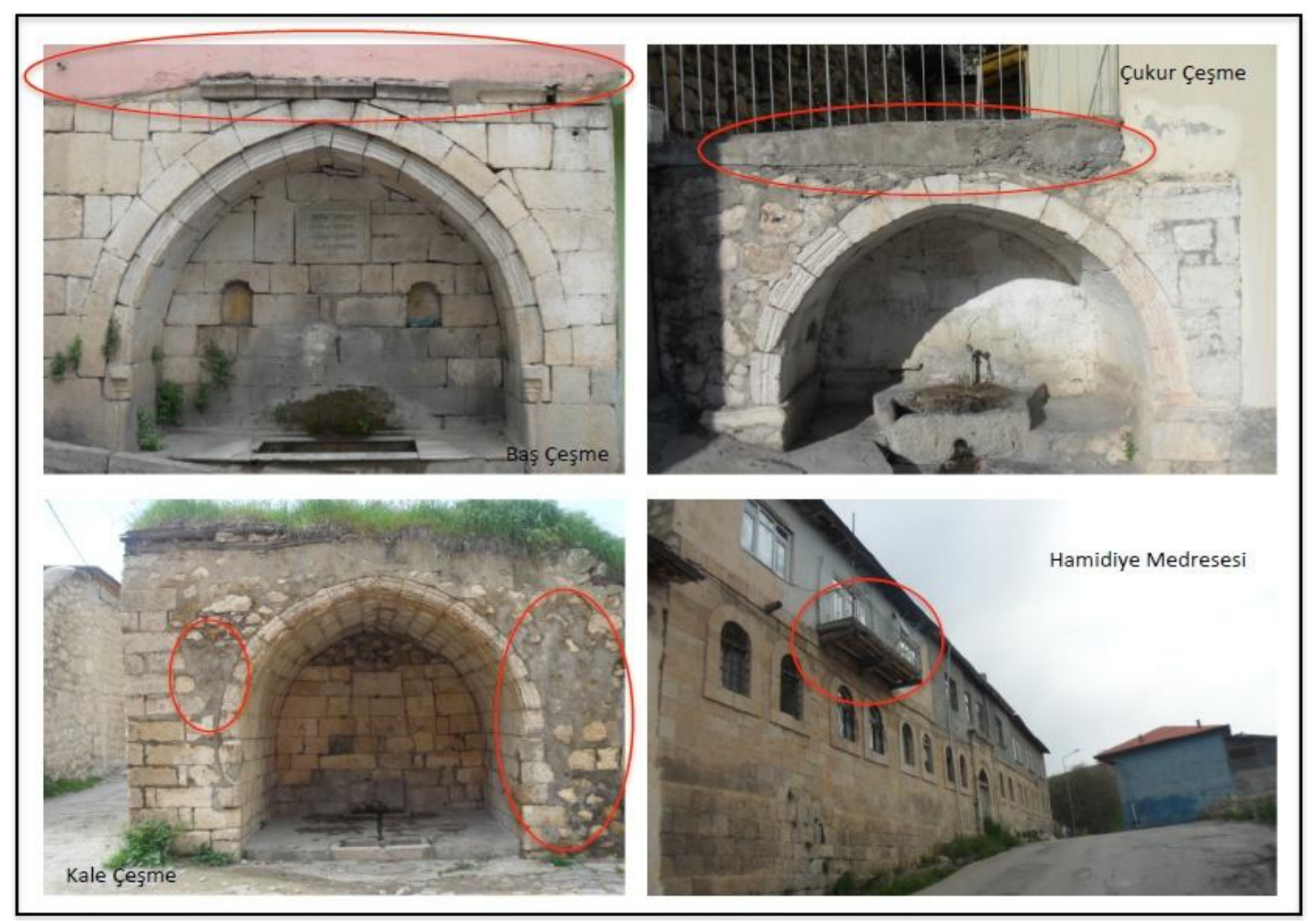

Şekil 3. Çemişgezek kent içindeki bazı tarihi yapılarda gözlenen bilinçsiz onarımlar

\subsubsection{Tahar (Yusuf Ziya Paşa) köprüsü}

Köprünün güney cephesinde büyük bir k1smı tahrip olmuş kitabe mevcuttur. Bu kitabede 1222/1807 tarihi okunabilmektedir. 1307 (1891-1892) tarihli MamuretÜl'aziz Salname'sinde, Çemişgezek'e $3 \mathrm{~km}$. mesafede Tahar Suyu üzerindedir. Gayet sanatkârane ve metindir. Yusuf Ziya Paşa tarafindan 1222/1807 de yaptırılmıştır. Köprüde meydana gelen bozunmalar, bitki ve mikroorganizma kolonizasyonunun neden olduğu kirlenmelerin yanında antropojenik (Graffiti) kirlenmelerdir. Ayrıca yer yer kılcal çatlak oluşumları da görülmektedir.

\subsubsection{Uzun hasan türbesi}

Türbenin, halk arasında Akkoyunlu Hükümdarı Uzun Hasan'a ait olduğu sanılmaktadır. İlçenin girişinde, Tekya mevkiinde, blok bir kaya üzerine inşa edilmiştir. Türbede gözlenen bozunmaları; kabuklanma, parça kopması, kirlenme, renk değişimi (kararması) ile yoğun bitki oluşumu olarak nitelendirilebilir. 


\subsubsection{Hamidiye medresesi}

Çemişgezek ilçe merkezinde bulunan Hamidiye Medresesi'nin kitabesinde yer alan bir ifadeden Sultan II. Abdülhamit zamanında 1861-1862 yıllarında yapıldı̆̆ anlaşılmaktadır. Yapıda meydana gelen bozunmalar arasında restorasyon amaçlı niteliksiz ekler dikkati çekmektedir. Ayrıca derz boşalması, aşınma, kılcal çatlaklar, yüzey erozyonu gibi bozunmaların olduğu gözlenmiştir.

\subsection{Yapı taşlarındaki bozunmalar}

\subsubsection{Taşın doğal yapısından kaynaklanan bozunmalar}

Çemişgezek'teki araştırma konusu yapılarının hasar tespiti çalışmalarımızın sonucunda, genel olarak taş yapısında oluşan çatlakların yanında yapı taşıyıcı sisteminde yapılan ilaveler ve eksiltmeler gözlenmiştir.

Toplanan bu veriler daha sonra değerlendirilerek bozunma faktörleri ve nedenleri belirlenmiştir. Yapıları oluşturan duvarların üzerine etki yapan düşey yüklerin yanı sıra depremlerin de bir sonucu olarak duvarlar üzerinde çatlaklar ile onları oluşturan taşlarda oluşan mikro-çatlakların yaygın olarak gözlenmesinin yanında taş aralarında derz malzemesinin de düşmesi sonucu geniş yarıklar saptanmıştır. Çok büyük bir olasılıkla bu mikro-çatlaklar zaman içerisinde büyüyerek çatlaklara dönüşmüş ve sonrasında da taştan parça ayrılmalarına neden olmuştur.

\subsubsection{Insanların neden olduğu bozunmalar}

Tarihi yapılarla ilgili hasara neden olan kaynaklardan belki de en önemlisi insanlardır. Kötü kullanım ve bakımsızlık veya terk etme, bilinçsiz onarım, vandalizm gibi çesitli şekillerde tarihi yapılarda önemli sayılabilecek bozunmalara neden olabilmektedirler. İnsan faktörünün olumsuz etkileri Çemişgezek'teki inceleme konusu yapılarda da görülmektedir. Özellikle Baş Çeşme, Çukur Çeşme, Kale Çeşme ile Hamidiye Medresesi'ndeki eklentilerin gerek yapıya birleştirilme şekli ve gerekse seçilen malzemenin uygunsuzluğu bariz bir şekilde dikkat çekmektedir.

Süleymaniye Camii (Şekil 4) ile Yelmaniye Cami'lerinde (Şekil 5) son dönemdeki onarımların yapıldığı duvar örgülerinde kullanılan çimentolu harçlar, özgün duvar örgülerinde kullanılmış olan kireç bağlayıcılı harçlara göre, gri/beyaz renkleri ile belirgin olarak farklılık göstermektedirler.

Günümüzde birçok tarihi yapı özel mülkiyet olduğundan ve kullanıcılarının istekleri doğrultusunda gelişigüzel ara kat, bölme duvarları ve dış cephe yüzeyinde oluşturulan bacalar gibi niteliksiz ekler ile sokak cephesine açılan pencereler yapıların orijinal görüntüsünü olumsuz yönde etkilemektedir. Yapıların artık kullanılmamalarından dolayı terk edilmeleri veya bakımsızlık ve kasıtlı tahrip gibi eylemlerle karşı karşıya kalması en sık karşılaşılan insan kaynaklı bozunmalardır. Bunların yanında yangınlar, savaşlar, vandalizm, imar çalışmaları, turizm, hava kirliliği ve yoğun trafik gibi yine insan kaynaklı etkenler de tarihi yapıların bozunmasını ve yok olmasını hızlandırmaktadır. 


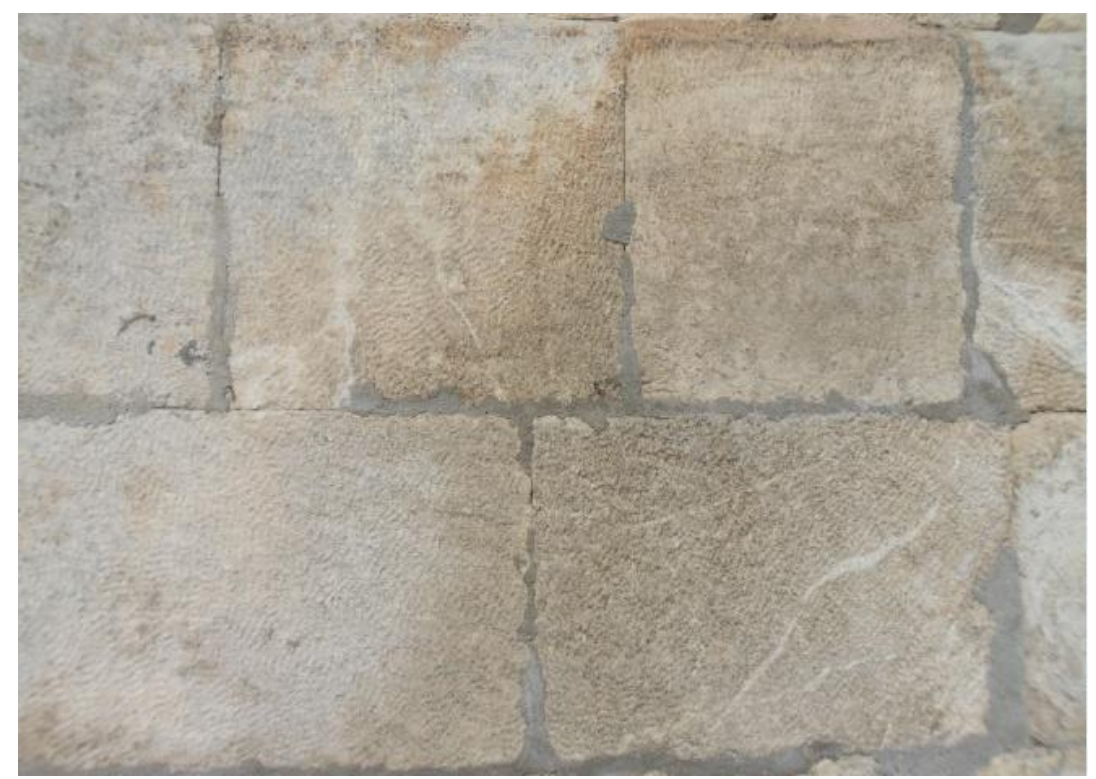

Şekil 4. Süleymaniye Camii derzlerinde çimento kullanımı

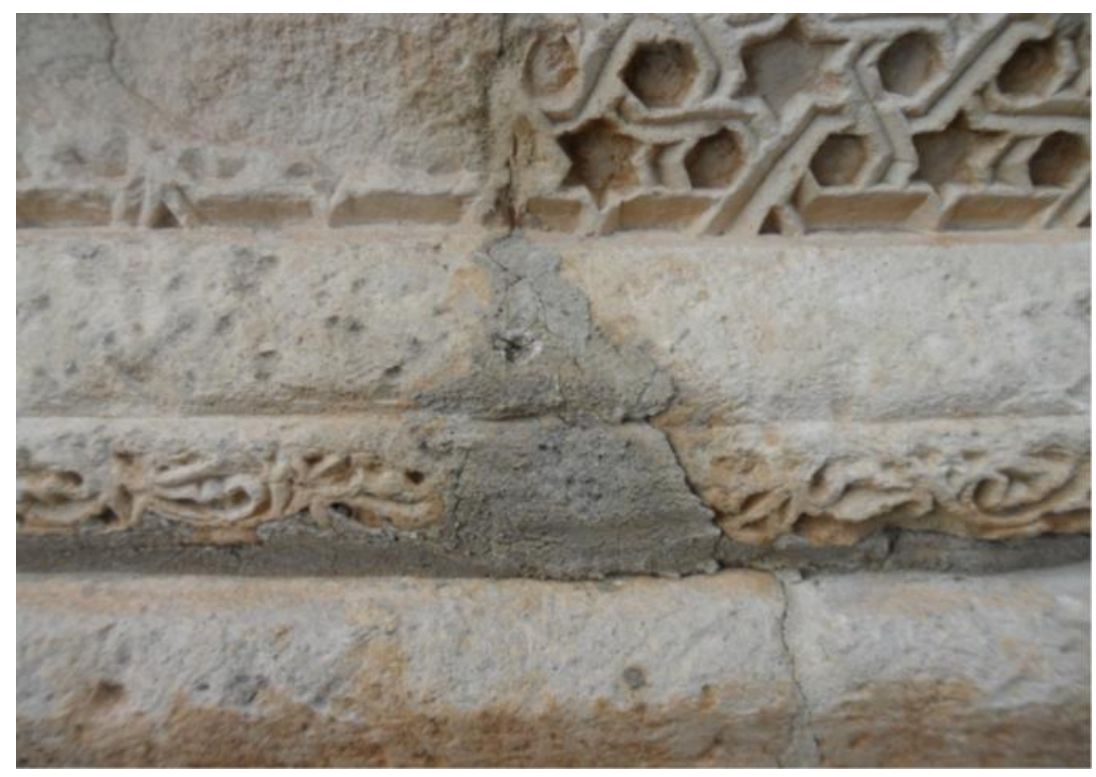

Şekil 5. Yelmaniye Camisinin bazı yerlerinde onarım amaçlı kullanılan çimento harcı

\subsubsection{Nemden kaynaklanan bozunmalar}

Çemişgezek bölgesindeki tarihi yapılarda kullanılan kireçtaşları, fosilli ve çatlaklı olmalarından dolayı kapilariteleri yüksektir. $\mathrm{Bu}$ sayede suyu emerek sürekli nemli kalmakta, bu da yosunların gelişmesine uygun bir ortam sağlamaktadır (Şekil 6). Bu nem ise taş yüzeyinde birikmelere ve kirlenmelere neden olarak taşların rengini değişmektedir. Yapılardaki yere yakın kısımlarda kullanılan taşların fazla harap olması bunun bir sonucudur. 


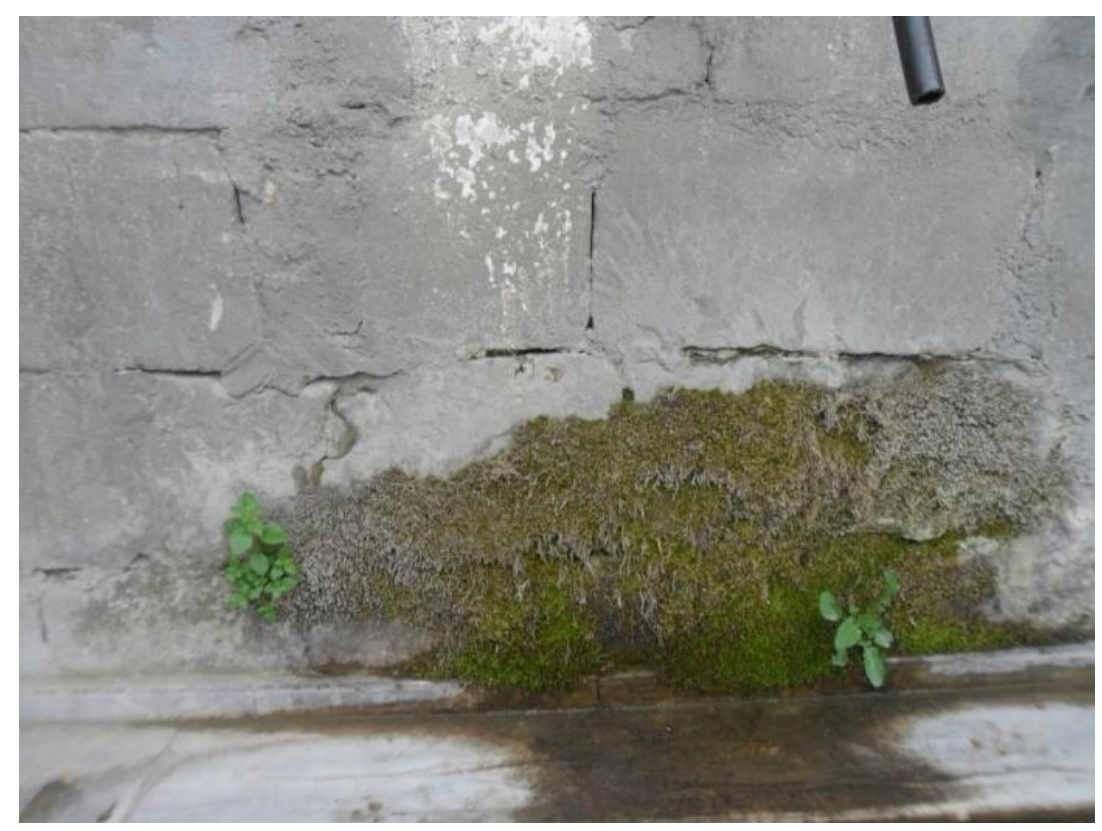

Şekil 6. Çemişgezek Baş Çeşmesi alt duvarlarında nemden dolayı gelişen yosunlar.

Taşın alt kısmındaki sular kapilerite sayesinde duvarın üst bölümlere yükselirken su ile birlikte erimiş tuzlar da taşın üst yüzeyine taşınır. Sıcaklığın artmasıyla artan buharlaşma nedeniyle, suyun kayaç yüzeyinden buharlaşması ile erimiş tuzlar orada birikir ve sert kabuklar oluşur (Şekil 7). Özellikle gözenek oranı yüksek olan taşlarda suyun yükselmesinden dolayı alt kısımlar kururken üst kısımlar nemli kalmakta, gözeneklerdeki suyun basınç oluşturması ile farklı dirençli kısımlar oluşmaktadır.

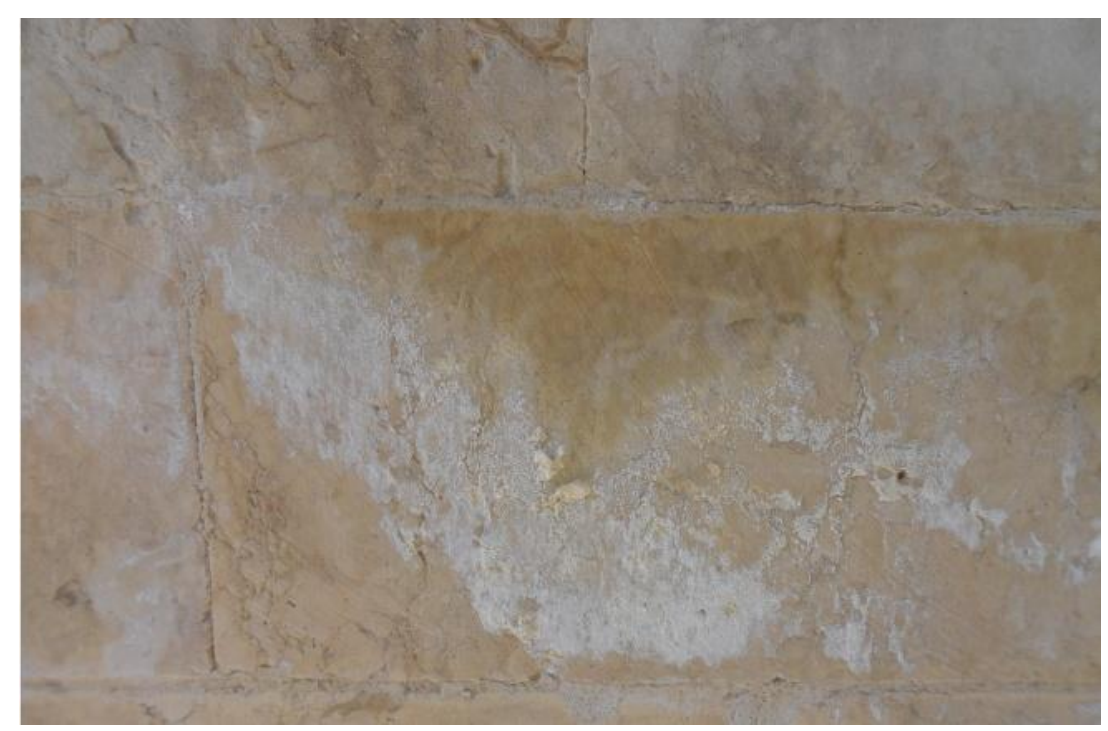

Şekil 7. Yelmaniye Camiinde tuz etkisiyle meydana gelen çiçeklenme

\subsection{4. İklimsel koşulların etkisi}

Yerel iklimin doğal bir sonucu olan donma-çözülme etkilerini, bu bölgede yer alan tarihi yapılarda görmek mümkündür. Yaz aylarında bölgede, gece ile gündüz arasında, yüksek değerlerde değişimler gösteren 1sı farklılıkları söz konusudur. Gündüz sicak etkisi ile genişleyen taş, geceleri soğur ve büzüşür. Buna bağlı olarak, gündüz, taşları oluşturan minerallerin hacimleri genişler, gece ise, sıcaklık düşmesi ile minerallerin hacimleri 
yeniden küçülür. Bu gerilim farkı ilk olarak dış katmanları etkilemeye başlar ve dış çeperin ince katmanlar halinde soyulmasına neden olur (Şekil 8).

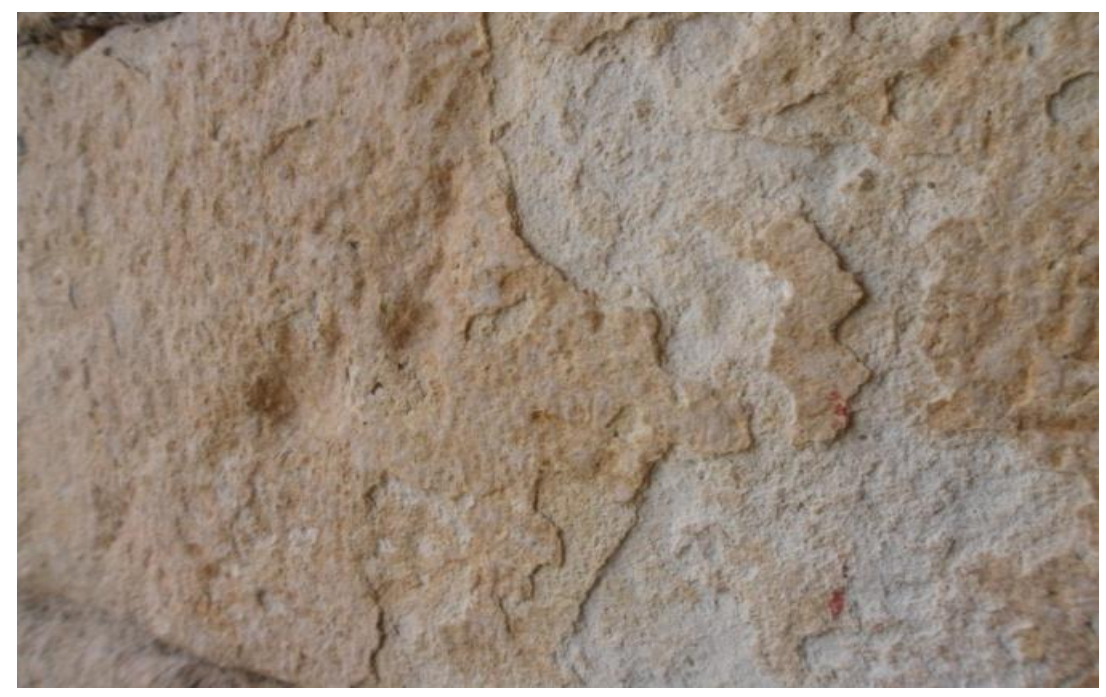

Şekil 8. Çemişgezek Kale Çeşme de katmanlar halinde soyulma

$\mathrm{Bu}$ durumun sürekli yinelenmesiyle kayaç eserlerde oluşan hacim değişikliğine bağlı olarak parçalanmalar ve çatlamaların oluştuğu Çemişgezek yapılarında da yaygın olarak gözlenmektedir (Şekil 9 ve 10).

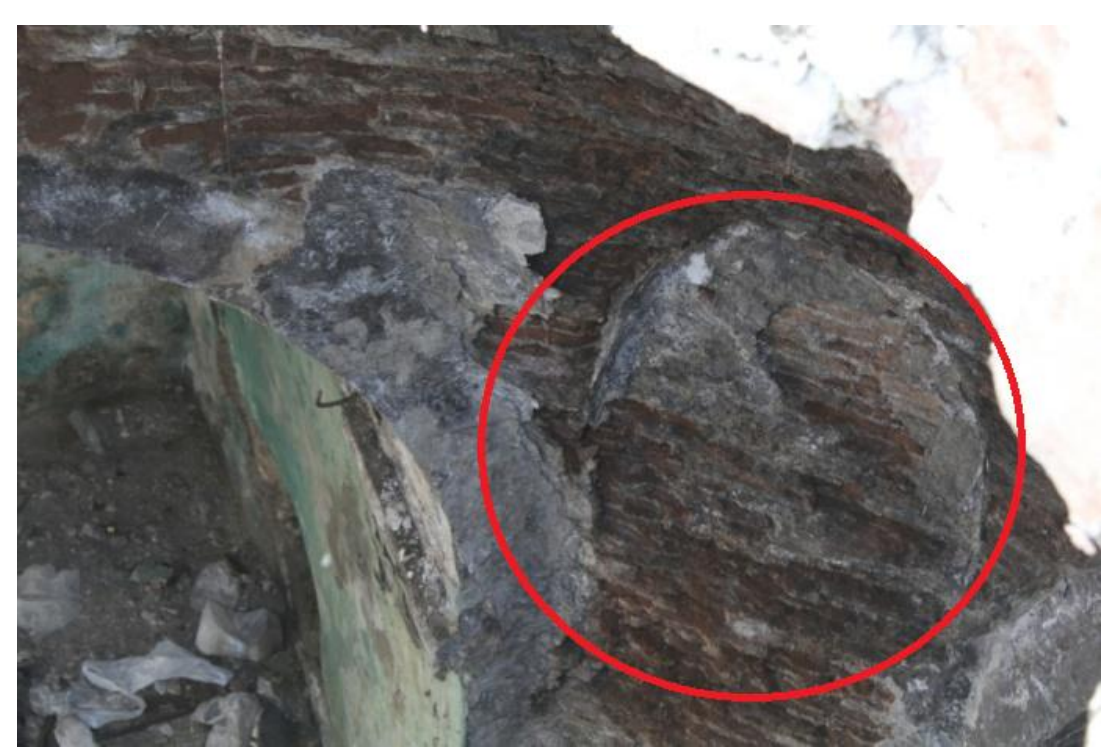

Şekil 9. Yeni Hamam da Sızan sulardan kaynaklı parça kopması

Bundan dolayı özellikle yığma yapılarda kullanılmış olan doğal taşlar zaman içinde asit yağmurlarının çevre koşullarının da etkisi ile harekete geçmesi taş yüzeylerinde erozyon oluşturdukları ve yapılarda önemli sayılabilecek nitelikte zarar oluşturdukları gözlenmiştir. Ayrıca, taşın az da olsa higroskopik (su emici) yapısından dolayı, bu asit yağmurları atmosferdeki kirlilikten de etkilenerek zaman içerisinde taş yüzeylerinin kararmasına neden oldukları yaygın olarak Çemişgezek'teki tüm yapılarda gözlenmektedir (Şekil 11 ve 12). 


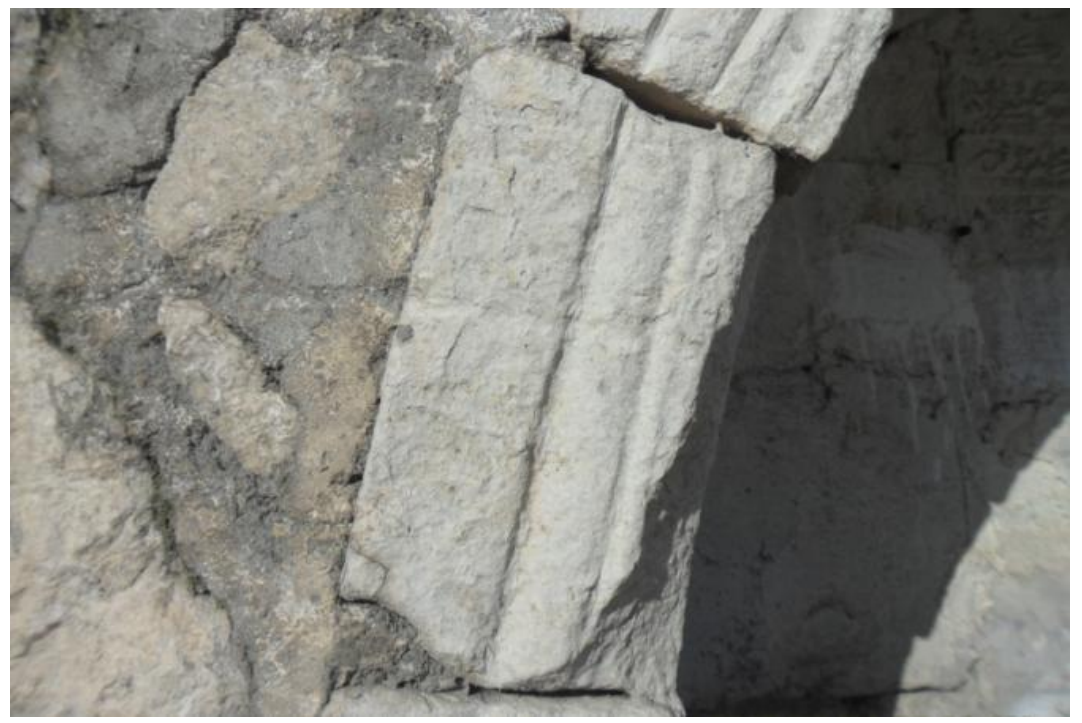

Şekil 10. Çukur Çeşme de Sızan sulardan kaynaklı parça kopması

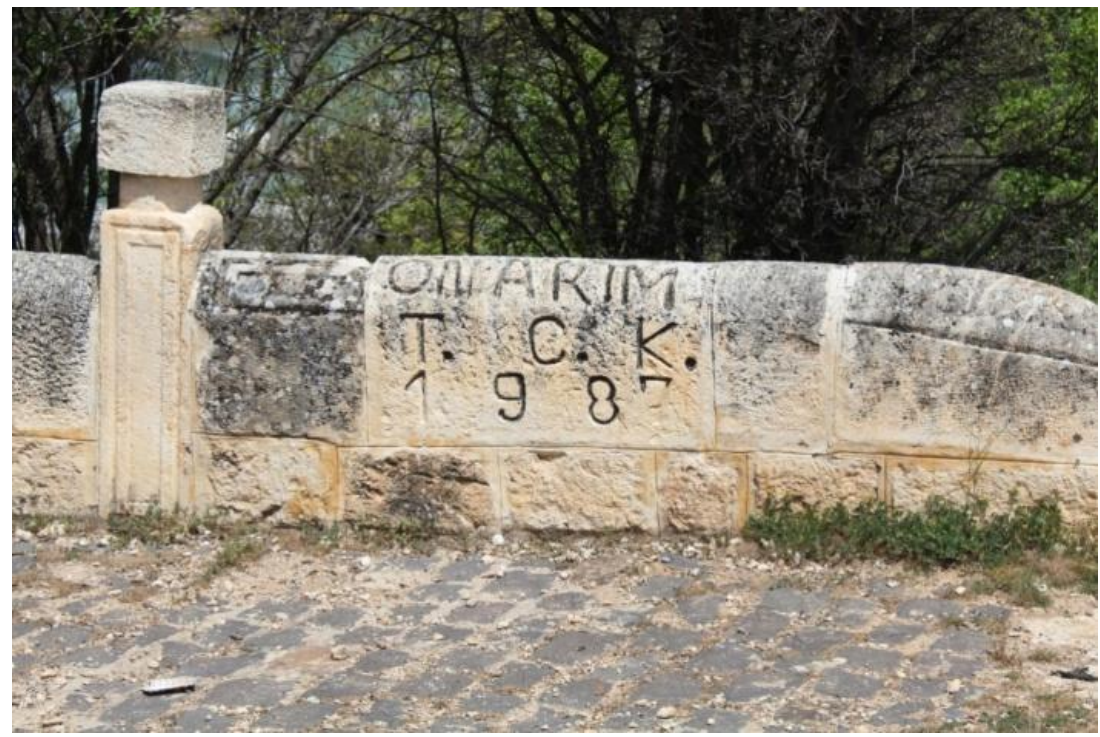

Şekil 11. Tahar (Yusuf Ziya Paşa) Köprüsü taşlarında gözlenen kararma. (Bu arada onarımla ilgili bilginin abartılı bir şekilde sunulması gözlerden kaçmamaktadır.)

Özellikle Yeni Hamam (Şekil 13) ile Atik Hamam (Şekil 14), terk edilmiş olmalarından dolayı, gerek kubbenin kendi ağırlığından ve gerekse üzerinde birikmiş toprağın neden olduğu aşırı yüklemelerden kaynaklanan hasarlar zaman içinde etkilerini göstererek yapıların kapı ve pencerelerinin çevresinde açılmalar oluşturduğu gözlenmiştir. 
DAL M., ÖCAL A.D.

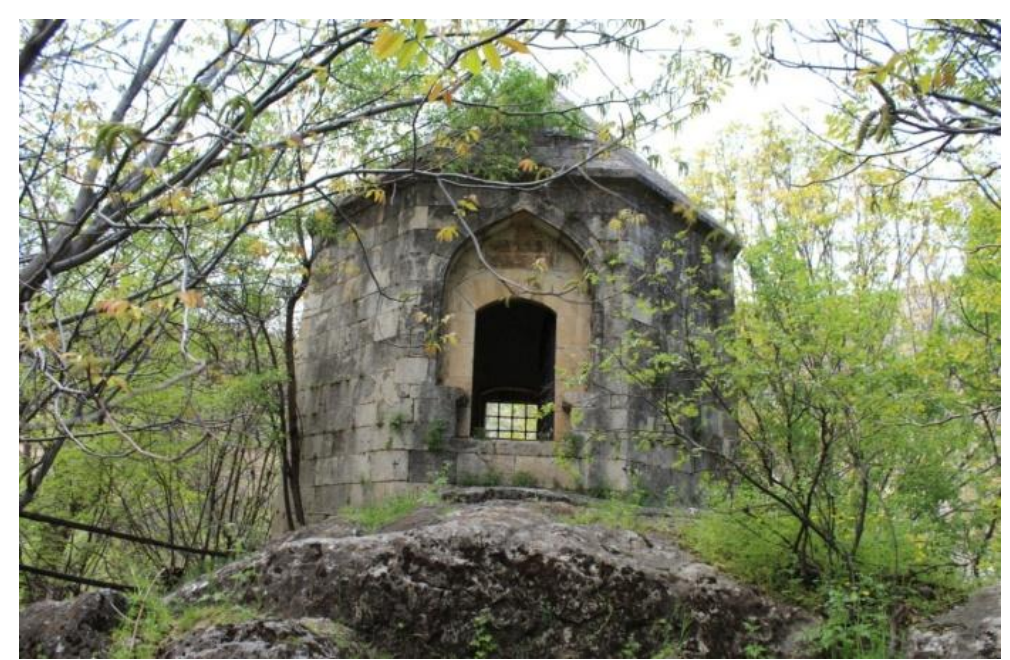

Şekil 12. Çemişgezek Uzun Hasan Türbesi duvarlarındaki kararma

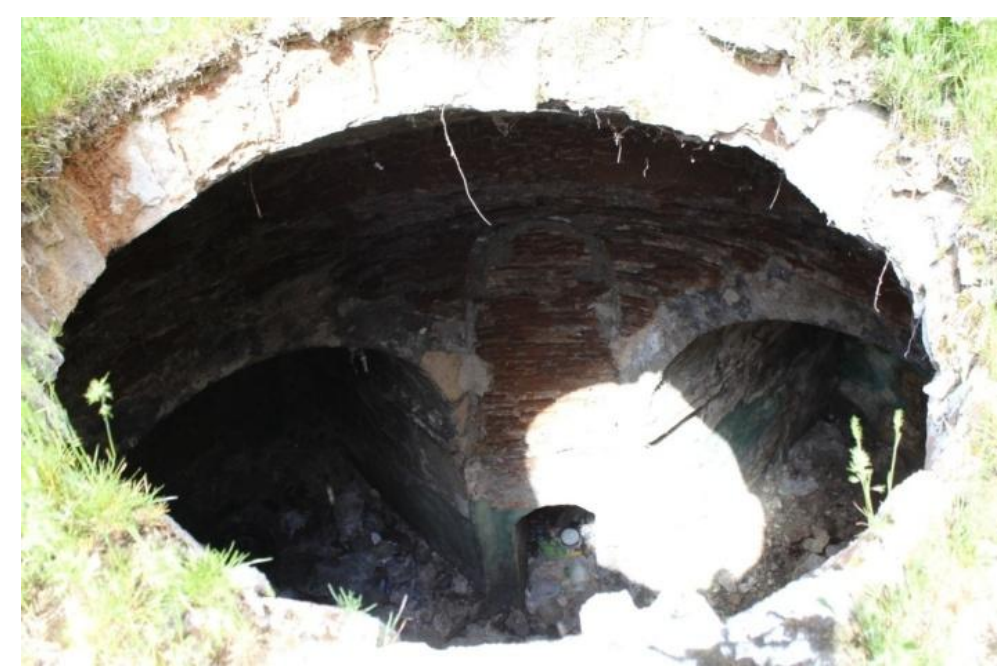

Şekil 13. Yeni Hamam da gözlenen, yapının terk edilmesinde dolayı tavan çökmesi

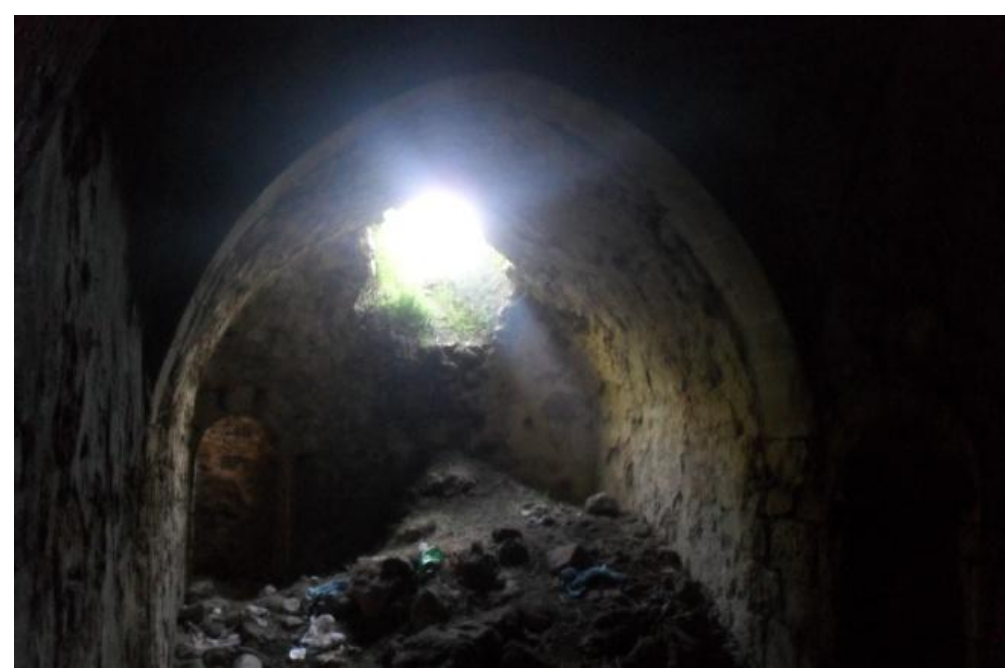

Şekil 14. Atik Hamam da gözlenen, yapının artık kullanılmamasından ve çatıdaki toprak birikiminin oluşturduğu tavan çökmesi 


\subsubsection{Hava kirliliğ $i$}

Şehir merkezinde özellikle kış aylarında fosil yakıtlarının yoğun olarak kullanımının sonucunda hava kirliliği ile malzemeye taşınan sülfat ve yoğun araç trafiği ile artan nitrat değerleri taşlarda öncelikle kararma ve sonra da yüzeyden itibaren dökülmelere yol açarak bozunum mekanizmalarının yoğun olarak işlemesine neden olmaktadır. Özellikle hava kirliliği nedeniyle karşılaşılan sorunlar; havada uçuşan tuz ve karbon parçacıkları veya sülfür gibi gazlar ile alkalin veya asit yağmurları olarak nitelendirilebilir. Yapıların dış cephelerinde gözlenen siyah tabaka atmosferik kirlenmeden kaynaklanmaktadır (Şekil 15). Çevrede endüstriyel bir yerleşim birimi olmamasına karşın uzun süren kış mevsimine bağlı olarak artış gösteren yakıt tüketimi ve egzoz gazları şehir merkezinde yoğun hava kirliliğine yol açmaktadır. Taş yüzeylerindeki bu birikim kar ve yağmur yoluyla oluşan nemli ortamda reaksiyona girip asidik bir etki yapmakta ve taşın esas bileşenlerinden kalsiyum karbonatı (kireç) jipse (alçı) dönüştürerek aşınmayı hızlandırmaktadır. Daha çok atmosfer kirlenmesinden kaynaklanan, kayaç yüzeyindeki kabuk oluşumu, gri renkten siyah renge kadar çok geniş bir çeşitlilik göstermekte, bazı koşullarda taşın orijinal yapısıyla bütünleşip taşın rengini değiştirebilmektedir.

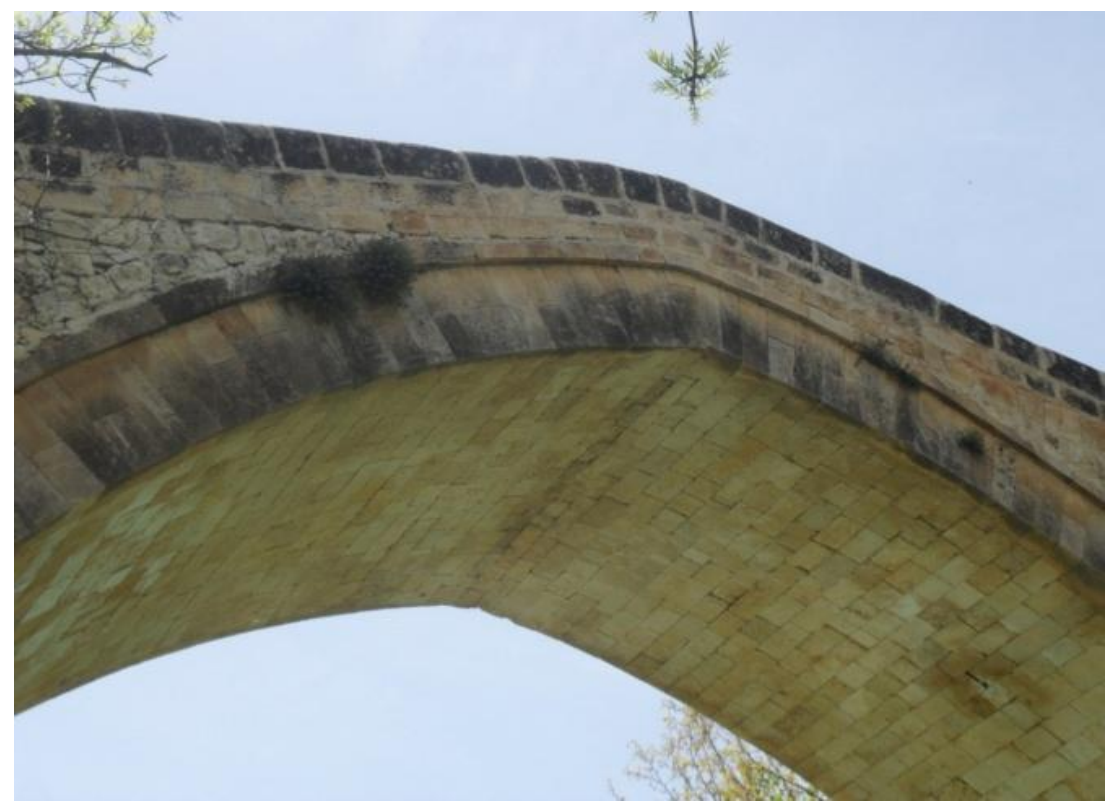

Şekil 15. Tahar (Yusuf Ziya Paşa) Köprüsünde atmosferik kirlenmeden kaynaklanan patina tabakasi

Atik Hamam ile Uzun Hasan Türbesinde gözlenen kabuklanma, taşın kendi yapısındaki morfolojik değişimlerin bir sonucu olabileceği gibi dışarıdan gelen organik veya inorganik kökenli yabancı maddelerin yüzeyde birikip kimyasal bir reaksiyonla kabuk haline dönüşmesi yoluyla da oluşabilmektedir. Genel olarak, sıcak-soğuk ile genleşmeçekme hareketlerine maruz kalan siyah tabakalar, yer aldıkları taş yüzeyinden farklı genleşme özellikleri nedeniyle bir süre sonra dökülmektedir.

Geçirgen olmayan bu siyah kabuklar yüzey için koruyucu bir tabaka teşkil etmemelerinin yanında kalsiyum karbonata göre yüksek çözünürlük ve gözenekliliğe sahip olan kalsiyum sülfat su infilitrasyonundan ve rekristalizasyondan sorumludur. Sülfatasyon ve korozyon süreci kabuk yüzeyi üzerinde mikro-çatlaklar oluşturmas1 nedeniyle devam edebilir. Bu nedenle, bozunma kabuk altında devam eder. Oluşan 
kabuğun kimyasal bileşimi ve fiziksel özellikleri taştan farklı olduğundan taşın bozunma hızını arttırmaktadır. Alçıtaşı (jips) kalsiyum karbonattan daha yüksek hacme sahiptir. Oluşumu taş yapı içinde gerilim meydana getirir ve bu gerilim malzeme kohezyonunu bozar ve büyük parçaların ayrılmasına neden olur. Farklı 1sıl genleşmeler ise siyah tabaka için daha çok önem arz etmektedir. Çünkü koyu renkler güneş ışınlarının daha çok emilimine neden olur. Bu da iç yüzey ile dış kabuk arasında farklı 1sıl genleşmelerden kaynaklanan bozunmalara sebep olmaktadır.

Hava kirliliğinin yoğun olduğu dönemlerde bu bozunmanın daha fazla gerçekleştiği görülmektedir. Taşlarda görülen sülfatlaşma olayı, kış aylarında artmaktadır. Yağmur sularının kimyasal etkisi ile, özellikle kalkerli yapı taşlarının, taşın dış tabakasının bir zar gibi iç bölümden ayrıldığı, küçük ve büyük plaklar halinde kopmaya başladığı görülür [13].

\subsubsection{Bitki oluşumu ve sonuçları}

Çemişgezek ilçesinde araştırılan tüm yapılarda bitki oluşumu gözlenmektedir. Büyük oranda rüzgarla taşınarak duvar dokusu içindeki derz boşluklarına yerleşen tohumların, giderek büyümesi ve bitki haline gelmesi, yapılarda ve taşlarda değişik türde bozunmalara neden olduğu gözlenmiştir. Özellikle Uzun Hasan Türbesi (Şekil 16), Atik Hamam, Yeni Hamam, Kale Çeşme yapılarının çatılarında çok yaygın bir şekilde bu bitki oluşumlarını görmek olasıdır. Hala kullanılmakta olmasına rağmen Süleymaniye Camiisi duvarlarında da bitki oluşumu gözlenmiştir (Şekil 17).

Yosunlar, nemli ortamda gelişerek biyolojik bozulmaya neden olabilmektedirler. Genellikle duvarların zemine yakın bölgelerinde taşın kapilaritesine bağlı olarak emilmesinden dolayı kolonizasyon şeklinde görülür. Çemişgezek'teki istisnasız tüm yapılarda yosun oluşumu gözlenmektedir. Özellikle çeşmelerin bulunduğu yerlerde yoğun olarak görülmektedir.

Taşın yüzeyine yerleşen sülfat ve nitrat üreten bakteriler önemli ölçüde taşın bozunmasına neden olmaktadır. Bitkiler pürüzlü ve nemli ortamda gelişerek, taşın nemini alır, kök salar ve taş yüzeyinde kir ve leke oluştururlar.

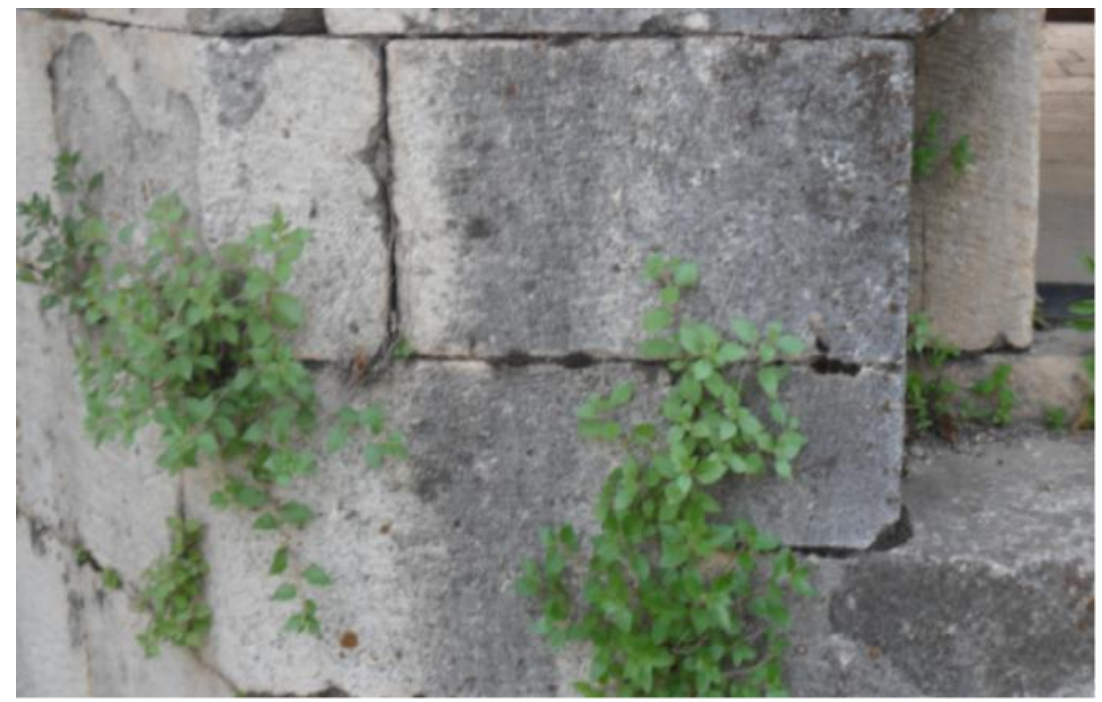

Şekil 16. Uzun Hasan Türbesi duvarlarında derzlerde gelişen bitki örtüsü 


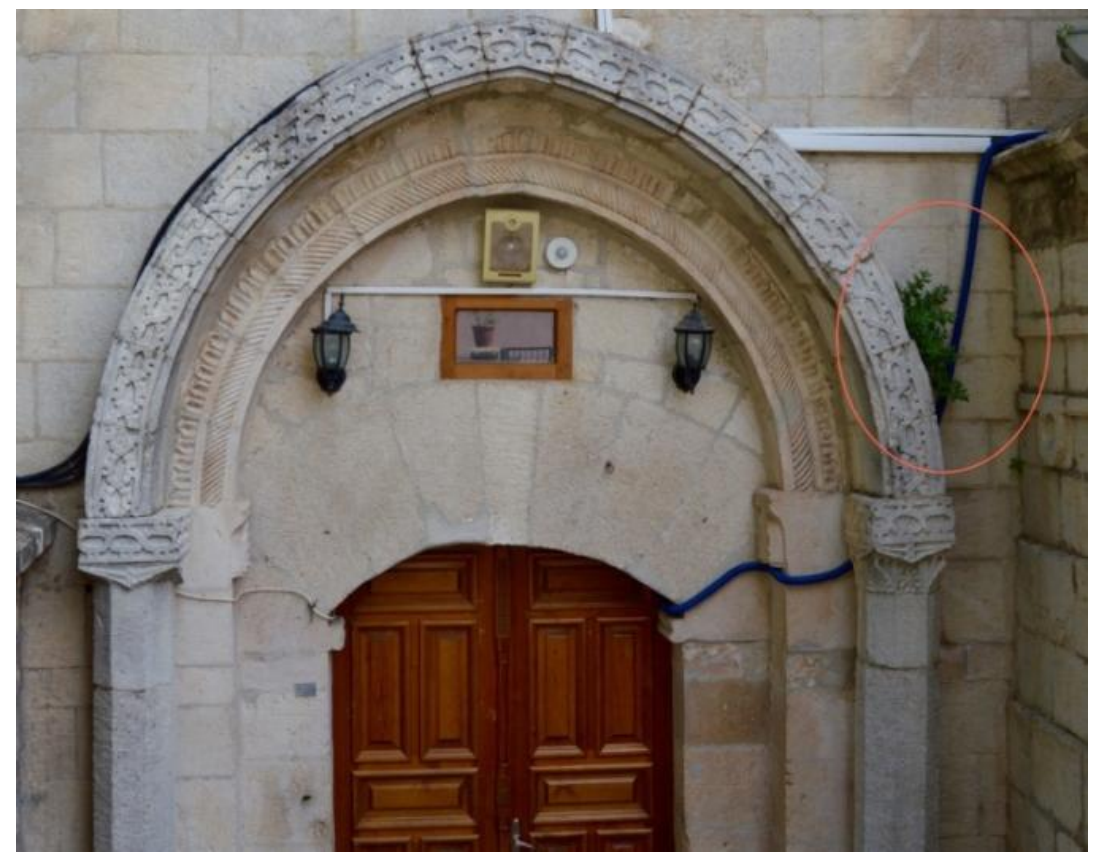

Şekil 17. Süleymaniye Camiisi giriş kapısının hemen üzerindeki derzlerde gözlenen biyolojik bozunma

Tahar (Yusuf Ziya Paşa) Köprüsünü oluşturan taşlarda yoğun mikroorganizma kolonizasyonu gözlenmektedir. Bunlar öncül biyolojik sistemler olan Siyanobakteri ve yeşil Algler'dir [13]. En önemli faktörlerden olan 1şık şiddeti, sıcaklık, $\mathrm{pH}$ ve nem bu mikroorganizmalar için optimum koşullar oluşturduğunda çoğalmaları için avantaj sağlarlar [14]. Büyümeleri en çok ilkbahar ve sonbahar aylarında belirgindir. Yeterince nemli ve direk güneş ışığına maruz olmayan tüm alanlarda da üreyerek gerektiğinde likenik oluşum da gösterirler [15]. Bu organizmalar oluşturdukları asidik ve alkali metabolitlerle hem estetik zararlara hem de taşın, kristal halinde partiküllere ayrışmasına neden olurlar. Taşın biyolojik olarak çözünmesi ile açığa çıkan kalsiyum, alüminyum, demir ve potasyum gibi elementleri ise kendi metabolizmalarında kullanırlar [16].

Yine Tahar Köprüsünde yoğun olarak gözlenen likenler, şekil ve yap1 bakımından kendilerini oluşturan alg ve mantarlardan tamamen ayrı bir yapı gösterirler. Su seviyesini çevre şartlarına göre değiştirerek yaşayabilen endolitik likenler, solunum yoluyla tallus içinde karbonik aside dönüştürülmüş olan $\mathrm{CO}_{2}$ üretirler ve kayada karbonik asit $\left(\mathrm{H}_{2} \mathrm{CO}_{3}\right)$ oluşumuyla da aşınmaya yol açarlar [17].

\section{Sonuçlar}

Türkiye'deki kültürel mirasın büyük bir bölümünü eski taş yapılar oluşturduğundan yola çıkarak, anıt eserlerin ve tarihsel yapıların korunması oldukça önemlidir. Çünkü kültür varlıklarının korunması, ulusal kültürün canlı tutulması ve tarihsel çevrenin yaşatılması için gereklidir. Bu doğrultuda, eski eserlerin ve tarihi yapıların, gelecekteki şehir planları içinde özgünlüğün korunarak sunulması tüm dünyada giderek daha büyük önem kazanmaktadır. Tarihsel sürecin kanıtları olan tarihsel yapıları bakımsız konumundan kurtarılarak hem yerel topluma hem de turizme uygun bir kültürel ortam hazırlamak tarihsel bilincin bir göstergesidir. Bu yapıların korunarak gelecek nesillere 
ulaştırılabilmesi için, görülen bozunma nedenlerini doğru bir şekilde belirleyip, gerekli önlemleri almak gerekmektedir. Bunun için de bu tarihsel öğelerin üstlendiği tarihsel değerleri gözünde bulundurarak bozunmayı yavaşlatarak ömürlerini uzatmak kültür varlıklarını korumanın temelini oluşturmaktadır.

Günümüzde uygulanan uluslararası koruma metodolojileri, belirli ilkelere bağlı bir program çerçevesinde geçerli olan kuramsal temellerle yapılmakta ve bunların ilk aşamasını da yapı ve anıt eserlerin ayrışma düzeyinin saptanması oluşturur. Çünkü taş türlerinin tam olarak tanınmamasından ve bozunma düzeylerinin açık bir şekilde sinıflandırılamamasından, yani bozunmanin ve bozunma etmenlerinin hatalı tanımlanmasından dolayı, sonrasında uygulanan birçok yöntemin uygunsuzluğu nedeniyle eski eserlerin daha fazla tahrip olduğu ile ilgili çok sayıda örneklerle karşılaşmak mümkündür.

\section{Kaynaklar}

[1] Fitzner, B., Documentation and evaluation of stone damage on monuments. In Kwiatkowski, D. and Löfvendahl, R. (ed.): Proceedings of the 10th International Congress on Deterioration and Conservation of Stone, Stockholm, ICOMOS, Sweden, 2, 677-690, 27 June - 2 July 2004.

[2] Kownatzki, R., Verwitterungszustandserfassung von Natursteinbauten unter besonderer Berücksichtigung phänomenologischer Verfahren. Aachener Geowissenschaftliche Beiträge, 22, (1997).

[3] Öcal, A.D. and Dal, M., Doğal Taşlardaki Bozunmalar, Mimarlık Vakfı İktisadi İşletmesi, İstanbul, (2012).

[4] Güner B., Çitçi D., Çemişgezek Kasabasının kuruluşu gelişmesi ve fonksiyonları, Fırat Üniversitesi Sosyal Bilimler Dergisi, Elazığ, 13, 1, 21-48, (2003).

[5] İlçi, Z., Tunceli ilinin Çemişgezek ilçesindeki tarihi yapılardaki hasarların görsel tespiti üzerine bir araştırma, Tunceli Üniversitesi, Mühendislik Fakültesi, İnşaat Mühendisliği Bölümü, Tunceli, (2015).

[6] Fitzner, B. and Heinrichs, K., Photo atlas of weathering forms on stone monuments. (2004) www.stone.rwth-aachen.de, (Erişim Traihi: 10.12.2004).

[7] Fitzner, B., Heinrichs, K. and Kownatzki, R., Weathering forms-classification and mapping. In: Snethlage, R. (ed.) Denkmalpflege und Naturwissenschaft, Natursteinkonservierung I. Ernst and Sohn, 41-88, Berlin, (1995).

[8] Fitzner, B. and Kownatzki, R., Klassifizierung der Verwitterungsformen und Kartierung von Natursteinbauwerken. Jahresberichte aus dem Forschungsprogramm Steinzerfall - Steinkonservierung, 1, 1-13, (1991).

[9] Siegesmund, S., Auras, M., Snethlage, R., Stein: Zerfall und Konservierung. Edition Leipzig, Leipzig, (2005).

[10] Vergès - Belmin, V., Anson Cartwright, T., Cassar, J., Charola, E., de Witte, E., Delgado-Rodriguez, J., Fassina, V., Fitzner, B., Fortier, L. and Franzen, C., An internet-accessible multilingual illustrated glossary on stone deterioration. Proceedings of the 10th International Congress on Deterioration and Conservation of Stone, ICOMOS, Stockholm, Sweden, 2, 699-706, 27 June-2 July 2004.

[11] Küçükkaya, A.G., Taşların Bozulma Nedenleri ve Koruma Yöntemleri, Birsen Yayınevi, İstanbul, (2004). 
[12] Dal, M. and Öcal, A.D. Investigations on Stone weathering of Ottoman Architecture: A Kirklareli Hizirbey Kulliye case study, Paripex-Indian Journal of Research, 2, 11, (2013).

[13] Caneva, G., and Roccardi, A., Harmful flora in the conservation of Roman monuments, Biodeterioration of cultural property. Proceedings of the International Conference,, Lucknow, India, 212-218, (1991).

[14] Tiano, P., Biodegradation of cultural heritage: Decay mechanisms and control methods, (2002) http://www.arcchip.cz/w09/w09_tiano.pdf 9th ARIEADNE Workshops, Prague, (Erişim Tarihi: 12.12.2002).

[15] Tomaselli, L., Margheri, M.C. and Florenzano, G., Indagine Sperimentale Sul Ruolo Dei Cianobatteri E Dellemicroalghe Nel Deterioramento Di Monumenti E Affreschi. In $3^{\circ}$ Congresso Internazionale Sul Deterioramento E Conservazionedella Pietra, Venezia, 313- 325, (1979).

[16] Şahiner, A., Tarihi yapıların biyolojik düşmanı küfler. Sanat Tarihi Dergisi 15, 1, 167-176, (2006).

[17] Dannin, A., Pitting Of Calcareous Rocks By Organisms Under Terrestrial Conditions. Israel Journal of Earth Sciences, 41, 201-207, (1992). 